\title{
Research on the Enrollment Model of Music Majors in American Comprehensive Universities
}

\author{
Kangyan Li \\ School of Music, Shaanxi Normal University, Xi'an 710119, Shaanxi, China \\ Email: 53859180@qq.com
}

\begin{abstract}
The enrollment model of music majors in American comprehensive universities is formed in the overall American social environment. In practice, it integrates the four elements of maintaining social fairness, abiding by admissions justice, following discipline rules, and emphasizing the ability of candidates. The optimal structure is formed. Thus, in the process of enrollment, it can not only maintain the fairness of society and the fairness of enrollment, but also follow the law of education to better predict the ability of students to succeed. This paper discusses that some good practices in the enrollment of music majors in the United States can be used for reference, such as the algorithm of GPA (Grade Point Average) scores, the defense link of the enrollment examination, the interview and so on.
\end{abstract}

Keywords: American comprehensive university, music major, enrollment model

The level of higher education in the United States is among the highest in the world, and its school-running philosophy, management system, and enrollment system are also unique. The author conducted a three-month survey at the University of Northern Colorado in the United States in 2019, the purpose of which was to investigate and study the actual operation and characteristics of the admissions model of music majors in comprehensive universities in the United States. The model is "the general way of the subject's behavior, which is the intermediary link between theory and practice, and has the characteristics of generality, simplicity, repetition, structure, and maneuverability" ${ }^{[1]}$. The enrollment model is a series of behaviors adopted by the education department when enrolling new students, which embodies and runs through the entire enrollment process. The enrollment model not only provides the academic framework for observing a country's enrollment situation for this study (the "Global University Enrollment Model” released by the World Bank in 2014 adopted this framework ${ }^{[2]}$ ), but also limits the research methods that must be used in this study. The methods are survey method, case study method, descriptive research method and explanatory research method.

\section{Selection of research objects}

American universities can be divided into comprehensive universities, colleges and community colleges according to the scale of schooling and the differences in degrees awarded. In the United States, there are more than 1,600 comprehensive universities that can grant music professional degrees, accounting for more than $95 \%$ of the schools that can grant music professional degrees. The author chose four comprehensive universities (two public universities and two private universities) where the music major has an advantageous position in all disciplines of the school for investigation and research. The four universities are University of Northern Colorado, University of State Colorado, Azusa Pacific University and Brigham Young.

\section{The enrollment process of music majors in American comprehensive universities}

\subsection{Qualification examination at the school level}

Each comprehensive university has absolute enrollment autonomy. Students applying for the school of music of a comprehensive university must pass the first round of qualification examination by the university admissions department. Standardized test scores are not the only condition for obtaining admission qualifications. Each school has its own different score standards. In addition, these four schools have other additional application conditions, and there are some subtle differences. The following are the basic materials required to apply for a comprehensive university. The information comes from the admission information webpage of each school. 
Table 1. Basic materials required to apply for a comprehensive university

\begin{tabular}{cccccc}
\hline University & GPA & $\begin{array}{c}\text { SAT or ACT } \\
\text { (Standardized test scores) }\end{array}$ & Personal statement & Recommendation letter & Additional factor \\
\hline UNC & Required & Required & Required & Required & $\begin{array}{c}\text { Outstanding academic } \\
\text { performance }\end{array}$ \\
CSU & Required & Required & Required & Required & Optional \\
APU & Required & Required & Required & Required & Optional \\
BYU & Required & Required & Required & Required & $\begin{array}{c}\text { Extracurricular activity } \\
\text { performance }\end{array}$ \\
\hline
\end{tabular}

It can be seen from Table 1 that in the enrollment process, the four comprehensive universities require candidates to provide four basic materials: "GPA", "Standardized test score", "Personal statement" and "Recommendation letter". Only in terms of additional materials, there are slight differences between universities. Only after passing the first round of material review and selection, can you enter the next round of interview of the school of music.

\subsection{Admission interview conducted by the school of music}

In the interview process of the schools of music of the four comprehensive universities, even if they are the same major, there are still certain differences in the interview content. Here are the contents of the interviews for piano performance (undergraduate), music education (undergraduate), and music history (master's degree) announced on the websites of these four schools in 2019.

Table 2. Interview content and requirements for piano performance major (undergraduate)

\begin{tabular}{|c|c|c|c|c|c|}
\hline University & Interview time & $\begin{array}{l}\text { Interview repertoire } \\
\text { requirements }\end{array}$ & $\begin{array}{c}\text { Whether } \\
\text { memorizing scores }\end{array}$ & Other playing skills & $\begin{array}{l}\text { On-site } \\
\text { defense }\end{array}$ \\
\hline UNC & $\begin{array}{l}3 \text { times in February } \\
\text { Once in March }\end{array}$ & $\begin{array}{l}\text { Three works of } \\
\text { different periods }\end{array}$ & Required & No clear requirement & Required \\
\hline $\mathrm{CSU}$ & $\begin{array}{l}\text { Once in January } \\
3 \text { times in February }\end{array}$ & $\begin{array}{l}\text { Two works of } \\
\text { different periods }\end{array}$ & Required & $\begin{array}{l}\text { Major and minor scale } \\
\text { and sight reading }\end{array}$ & Required \\
\hline APU & $\begin{array}{l}5 \text { times in April } \\
3 \text { times in February } \\
\text { Twice each in January and October } \\
\text { Once each in March and November }\end{array}$ & $\begin{array}{l}\text { One Bach work, one classical } \\
\text { sonata allegro, one romantic } \\
\text { period work }\end{array}$ & Required & No clear requirement & Required \\
\hline BYU & $\begin{array}{l}\text { Twice in January } \\
\text { Once in November }\end{array}$ & $\begin{array}{l}\text { One Bach work, one classical } \\
\text { sonata full movement, one } \\
19 \text { th and } 20 \text { th century work }\end{array}$ & Required & Major and minor scale & Required \\
\hline
\end{tabular}

Table 3. Interview content and requirements for music education major (undergraduate)

\begin{tabular}{|c|c|c|c|c|}
\hline University & Interview time & Interview repertoire requirements & Other requirements & On-site defense \\
\hline UNC & $\begin{array}{l}3 \text { times in February } \\
\text { Once in March }\end{array}$ & $\begin{array}{l}\text { Musical instrument performance or } \\
\text { vocal performance }\end{array}$ & No clear requirement & Required \\
\hline $\mathrm{CSU}$ & $\begin{array}{l}\text { Once in January } \\
3 \text { times in February }\end{array}$ & $\begin{array}{l}\text { Musical instrument performance or } \\
\text { vocal performance }\end{array}$ & No clear requirement & Required \\
\hline APU & $\begin{array}{c}5 \text { times in April } \\
3 \text { times in February } \\
\text { Twice each in January and October } \\
\text { Once each in March and November }\end{array}$ & $\begin{array}{l}\text { Musical instrument performance or } \\
\text { vocal performance }\end{array}$ & No clear requirement & Required \\
\hline BYU & $\begin{array}{l}\text { Twice in January } \\
\text { Once in November }\end{array}$ & $\begin{array}{l}\text { Musical instrument performance or } \\
\text { vocal performance }\end{array}$ & $\begin{array}{l}\text { Taking a course in pedagogy } \\
\text { is required }\end{array}$ & Required \\
\hline
\end{tabular}

Table 4. Interview content and requirements for music history majors (master students)

\begin{tabular}{|c|c|c|c|c|}
\hline University & Interview time & Interview content & Reference conditions & On-site defense \\
\hline UNC & An interview is not required & None & $\begin{array}{l}\text { Upload personal materials and } \\
\text { academic articles }\end{array}$ & None \\
\hline $\mathrm{CSU}$ & $\begin{array}{l}\text { Once in January } \\
3 \text { times in February }\end{array}$ & Written test & Upload personal materials & None \\
\hline BYU & $\begin{array}{l}\text { Twice in January } \\
\text { Once in November }\end{array}$ & $\begin{array}{l}\text { Written test and second } \\
\text { foreign language test }\end{array}$ & $\begin{array}{c}\text { Upload personal materials and } \\
\text { academic articles }\end{array}$ & None \\
\hline
\end{tabular}




\section{The characteristics of the enrollment model of music majors in American comprehensive universities}

Compared with the enrollment model of music majors in Chinese universities, the enrollment model of music majors in American comprehensive universities has the following characteristics.

\subsection{Fully autonomous enrollment}

Conservatories of comprehensive universities in the United States have adopted a completely independent enrollment model due to their different attributes and school-running ideas. Organizing exams, determining the content and scope of the exams, and determining the admission results are entirely done by the college. This completely autonomous enrollment model can better predict students' ability to succeed in the future. Take the piano performance professional interview as an example. As both APU and BYU are private church universities, Bach's works are required to be tested. UNC and CSU have no requirements, which means that you can choose the works of other composers in the same period. In addition to the performance of the works, CSU and BYU also examine the basic scale and key performance. CSU will also examine sight readings. In addition to solo performances, students studying piano performance may cooperate more with chamber music, vocal solo or chorus. Therefore, having a certain sight-reading ability is valued by CSU.

\subsection{Humanized and flexible management}

American universities have embodied humanized and flexible management in the admissions process of music majors. First of all, various university music majors organize multiple interviews every year. From the data of the above four universities, BYU has the least number of interviews, three times a year; APU has the most number of interviews, twelve times a year. Students who are unable to participate in an interview can also make a new appointment with the school to take a separate exam. Professor Janet of CSU mentioned that because Colorado often encounters extreme snow and hail weather that makes students travel dangerous and difficult, the college can break the interview schedule and provide students with additional opportunities for interviews. In addition, if students have real difficulties, they cannot go to the school for an interview. For some majors, they may not participate in the interview and provide performance videos to the school instead.

\subsection{Standardized test scores are a prerequisite for admissions}

American comprehensive university music schools attach importance to standardized test scores, which is a prerequisite for admission. Different from our country's high-efficiency music majors enrollment model, for GPA scores and SAT or ACT scores, comprehensive universities in the United States apply the same standards for music majors and other majors. "SAT and ACT are indeed important to most colleges and universities, because they have the highest reliability and validity in predicting the success of colleges in the world in similar tests" ${ }^{[3]}$. Although standardized test scores are not the only admission requirement, Professor Leiweng from UNC said that UNC attaches great importance to applicants' GPA scores and SAT or ACT scores. According to experience, students with excellent standardized test scores are usually directly proportional to their academic performance in the school. Standardized test scores directly affect the amount of scholarships for UNC Conservatory of Music.

\subsection{The test content determined by the interview is related to the subject direction}

The content of the exams is very targeted during professional interviews in American comprehensive university music schools. In terms of knowledge and skills, the content and requirements of the exam are based on the subject direction of each major. For practical majors such as instrumental music performance and vocal music singing majors, interviews are centered on skill display. Music education majors need to provide complete teaching videos. For theoretical majors such as music history and music theory majors, special interviews are not necessary. But students are required to complete multiple undergraduate courses in musicology and pedagogy before applying for a master's degree in music theory, and submit published academic papers and short essays on academic opinions to examine the level and ability of academic research that students have. In terms of students' emotional attitudes and values, as long as there is an interview, on-site defense is indispensable. During the defense process, the jury generally asked the following questions: Why did you choose this major? Why choose this school? What are your plans for future studies and careers? At the same time, the jury will also test students' manners, speech, personality, and thinking, and make judgments on whether they are competent for future studies and careers. Candidates should answer any questions raised by the jury. 


\subsection{The discretion of the judges in the interview is restricted by the scoring standards and the confirmation procedures}

First of all, the professors must follow the meticulous scoring standards to score and give written comments. It seems that they are exercising "freedom" but are restricted by the scoring standards. Second, the large-scale interview organized by the school usually involves five (or other odd-numbered) professors participating in the evaluation, and the final determination is made according to the principle of the minority obeying the majority, so as to avoid the situation that the professors are stuck in their own opinions and lead to a deadlock. In special circumstances, such as the jury has only four (or other even-numbered) professors, and there are two-to-two (or equal) opposite opinions, the APU Conservatory of Music adopts the method of debate and negotiation first. If it still fails, it will be The three (music performance, music business management, musicology) heads of the college and the most authoritative professors formed a ruling team to make the final ruling. The method adopted by the UNC Conservatory of Music is that the dean of the Conservatory of Music comprehensively considers the scores and comments of each professor before making a final decision. The CSU Conservatory of Music has a harmonious atmosphere. If students cannot meet the requirements of the school's enrollment level for the time being, but the students are very eager to get the opportunity to learn, the jury will even give students the opportunity to try for a semester, and if the students can meet the requirements through the trial, Then they can stay and continue studying.

\section{The experience of other countries can be used for reference}

Now that China has become the world's second largest economy, and people's livelihood and education have also achieved a qualitative leap. Beginning in 1999, undergraduate enrollment in colleges and universities across the country has been expanded year by year. By 2018, the gross enrollment rate of higher education in the country reached $48.1 \%$, and the number of applicants for art majors in colleges and universities nationwide exceeded one million in 2018. This indicates that my country's higher education is about to enter the popularization stage from the popularization stage ${ }^{[4]}$.

Facing the new social situation and new requirements, the admission of art majors also faces new challenges. China implements a highly unified centralized power system in management. Educational undertakings are planned by the Ministry of Education and enforced in all provinces across the country. The annual music professional admission examination is also organized and implemented by the provincial education authorities appointed by the Ministry of Education. Except for the enrollment organized by the respective professional music schools, most of the music majors of comprehensive universities have been included in the music major joint examinations organized by the provincial education administrative departments. The advantage of this is that the professional examination process and performance evaluation are basically open, fair and just, but it is still a huge problem to select talents who are truly suitable for studying music. Therefore, we can learn from some good practices in the admissions of American music majors.

\subsection{Learn from the GPA algorithm to calculate the average grade point score by weighting cultural and professional courses}

The cultural literacy of music majors is generally not high. Many students attacked "strengthening" art subjects because they were unable to get up in the cultural course and were unable to enter other majors in the university, and took "shortcuts" with utilitarian purposes. Although in recent years some people have been calling for the improvement of the admission scores for arts majors and cultural courses, some provinces have indeed raised the corresponding admission scores for music majors, but with little effect. To measure a person's musical talent and subsequent development motivation, various indicators should be considered comprehensively. We can learn from the algorithm of American GPA scores, set a minimum score for each of the cultural and professional courses, weight the cultural and professional courses to calculate the average GPA, and then select the best from the highest to the lowest.

\subsection{Learn from the defense link of the admissions examination to test the candidates' ability to succeed}

The highly uniform content and format of the music professional examinations are difficult to highlight the key points of knowledge that need to be examined in different professional directions, and it is difficult to examine the qualities and abilities of students in addition to professional skills. Each professional discipline of musicology focuses on the selection of talents. Under the background that my country puts social fairness first in enrollment, it is unrealistic to change the content of highly uniform professional examinations. Therefore, you can consider adding a short answer to the entrance examination for music education. By answering one or two questions raised by the review team, one is to check whether 
the student's speech is clear, and the other is to understand some situations outside of knowledge and skills (personality, emotional intelligence, etc.), so as to realize the test of the test generation function.

\subsection{Learn from the interview method, and each school will set up an interview session according to its own training goals}

The training goals of music majors in each university will not be exactly the same, so the exact same criteria cannot be used to select students in the enrollment process. However, the current non-differentiated entrance examination for music majors in my country cannot meet the differentiated demands of various schools. In this regard, we can learn from the enrollment model of music majors in comprehensive universities in the United States, and let each school set up an interview link according to its own training goals and enrollment requirements. The content and format of the examination are determined by each school.

As the World Bank's "Global University Admissions Model" pointed out, "The issue of fairness in admissions is very complicated. Different nodes in the admission process and the larger socio-economic environment of a country or region must be considered." Therefore, it must be realized from different perspectives. Fair ${ }^{[5]}$. In China, when the unified university entrance examination is unanimously regarded as the best choice to ensure fairness and justice, comprehensive university music majors should be supplemented and perfected in more specific links, which is not only necessary but also completely feasible.

\section{References}

[1] Chen Shiqing. Glossary of Symmetric Economics (20). Available from: http://www.mea.com.cn/blog/read.php?823, 2017-06-05.

[2] Meng Qingtao, He Mei, Wu Xiangrong. The World Bank report "Global University Admissions Models" proposes that fairness and justice are the goal of the reform of the admissions system. China National Education. 2016(1):44.

[3] Doran N J. Correspondence between ACT and SAT I scores (The College Board Rep.99-1;ETS Research Rep.RR.,No.99-2). New York: College Entrance Examination Board; 1999.

[4] Ministry of Education. Higher education in China is about to enter the popularization stage. Available from: http:// edu.people.com.cn/n1/2019/0227/c1006-30904726.html.

[5] Meng Qingtao, He Mei, Wu Xiangrong. University Admissions: See How the World Bank "Takes the Pulse". China Education News; 2014- 6-16 (21). 